\title{
Structure of the Hatton Basin and adjacent continental margin
}

\author{
L. K. SMITH, ${ }^{1}$ R. S. WHITE ${ }^{1}$, N. J. KUSZNIR ${ }^{2}$ and iSIMM Team ${ }^{3}$ \\ ${ }^{1}$ Bullard Laboratories, University of Cambridge, Madingley Rd, Cambridge CB3 OEZ, UK \\ (e-mail: lsmith@esc.cam.ac.uk) \\ ${ }^{2}$ Department of Earth Sciences, University of Liverpool, Liverpool L69 3BX, UK \\ ${ }^{3}$ iSIMM Team comprises P. A. F. Christie, N. J. Kusznir, A. M. Roberts, R. S. White, R. Spitzer, L. K. Smith, \\ Z. C. Lunnon, C. J. Parkin, A. W. Roberts, N. W. Hurst and V. Tymms
}

\begin{abstract}
In the summer of 2002, new data were acquired along wide-angle and normal-incidence profiles extending from the Hatton Basin, across the adjacent Hatton Bank volcanic continental margin and into the Iceland Basin. Eighty-nine four-component ocean-bottom seismometers (OBS) were deployed along a transect running across the continental margin and along two strike lines located above the region of thickest extrusive and intrusive igneous rock on Hatton Bank and over $44 \mathrm{Ma}$ oceanic crust near the end of the main dip profile. The seismic profiling was optimized for large offset OBS arrivals with a low-frequency airgun source centred at $10 \mathrm{~Hz}$. Wide-angle seismic energy penetrated the extruded basalt, the underlying crust and well into the upper mantle. Initial modelling results from Hatton Basin show a $\sim 4 \mathrm{~km}$ thick sedimentary sequence and provide a new sub-sediment crustal thickness estimate of $\sim 15 \mathrm{~km}$. This crustal thickness suggests a stretching factor of two relative to the continental crust under Rockall Bank. These new results have been integrated with an established model for the region to demonstrate the variations of crustal structure across the margin. Future processing and modelling of the extensive dataset collected in the 2002 survey will allow refinement of the crustal structure model across the stretched continental crust beneath Hatton Basin and the adjacent continental margin. In particular it will place better constraints on the intrusive and extrusive igneous components produced during continental break-up in the Palaeogene.
\end{abstract}

Keywords: Hatton Basin, Hatton Bank, magmatism, rifted margin, continental stretching, ocean-bottom seismometers

The northern North Atlantic margins are a classic example of continental break-up in the presence of a thermal anomaly in the mantle thought to be caused by a mantle plume (White 1992, 1997; Eldholm \& Grue 1994). The elevated mantle temperatures caused voluminous magmatism at the time of continental rifting in the early Cenozoic (59-56 Ma). The greater part of the new igneous material generated by partial melting of the mantle remained in the lower crust (White \& McKenzie 1989) and together with widespread sill intrusions had the effect of producing permanent uplift around the margins of the North Atlantic (White \& Lovell 1997). The rest of the melt migrated to the surface and was erupted at the time of continental break-up; a minimum estimate of extruded volcanic rocks is $1.8 \times 10^{6} \mathrm{~km}^{3}$ with an areal extent of $1.3 \times 10^{6} \mathrm{~km}^{2}$ (Eldholm \& Grue 1994). This material was extruded as lava flows and pyroclastic deposits (White \& McKenzie 1989), which extended across potentially hydrocarbon-bearing basins on the Atlantic margin (e.g. Richardson et al. 1999).

Seismic reflection profiling around the North Atlantic has been used successfully to characterize the upper crustal structure of the volcanic margins. The extruded basalts on the margins are typically expressed as seaward-dipping reflector (SDR) sequences, the source of which is generally agreed to be vents at the currently downdip end of the reflectors (Hinz 1981; Mutter et al. 1984; Spence et al. 1989). These SDRs extend along more than $2500 \mathrm{~km}$ of the rifted continental margins in the northern North Atlantic on both the European and Greenland sides (Eldholm et al. 1989; White \& McKenzie 1989; Larsen \& Saunders 1994).

The basalts extruded during rifting have hindered the ability of conventional seismic reflection profiling to resolve the deep crustal structure of the rifted volcanic margins and the adjacent basins. The strong impedance contrast between the basalts and the overlying sediments and the heterogeneous nature of the basalts themselves restrict the penetration of seismic energy at normal incidence, as most seismic energy is reflected or scattered from and within the basalt layers, masking weak reflections from the deep sub-basalt structure. To overcome the imaging problems posed by the extruded basalts, several wide-angle seismic surveys have been made of the continental margins on both sides of the northern North Atlantic (Fig. 1) (e.g. Fowler et al. 1989; Morgan et al. 1989; Keser Neish 1993; Barton \& White 1997; Vogt et al. 1998; Smallwood et al. 1999; Korenaga et al. 2000; Holbrook et al. 2001; White et al. 2002; Breivik et al. 2003; Hopper et al. 2003). These surveys have increased our understanding of the evolution of the margins and have shown the lower crust in these regions to be characterized by high velocities $(7.1-7.5 \mathrm{~km} / \mathrm{s})$ beneath the extruded SDRs. However, the deep intra-crustal structure and nature of the characteristic high-velocity layer in the lower crust are still unclear; the lower crustal high-velocity layers may consist of a mixture of intruded magmatic material and blocks of lower continental crust or may consist entirely of underplated igneous rocks (e.g. White \& McKenzie 1989; Mjelde et al. 1992; Barton \& White 1997). It has therefore been difficult to quantify the total amount of new igneous material generated at these volcanic margins or to understand fully the processes involved in its emplacement and consequently the history of formation of the North Atlantic margins.

The integrated Seismic Imaging and Modelling of Margins programme (iSIMM), an academic-industry collaboration, collected new data in the summer of 2002 across two continental margins in the North Atlantic, one in the Hatton Bank region and the second in the region east of the Faroe Islands (Lines C \& G, Fig. 1). Results from the Faroes survey are discussed in Roberts et al. (2005). These surveys were designed to target specifically the lower crust across the margins and to investigate the influence of the Iceland mantle plume on their formation and evolution. This

Smith, L. K., White, R. S., Kusznir, N. J. \& iSIMM Team. 2005. Structure of the Hatton Basin and adjacent continental margin. In: Doré, A. G. \& Vining, B. A. (eds) Petroleum Geology: North-West Europe and Global Perspectives-Proceedings of the 6th Petroleum Geology Conference, 947-956. (C) Petroleum Geology Conferences Ltd. Published by the Geological Society, London. 


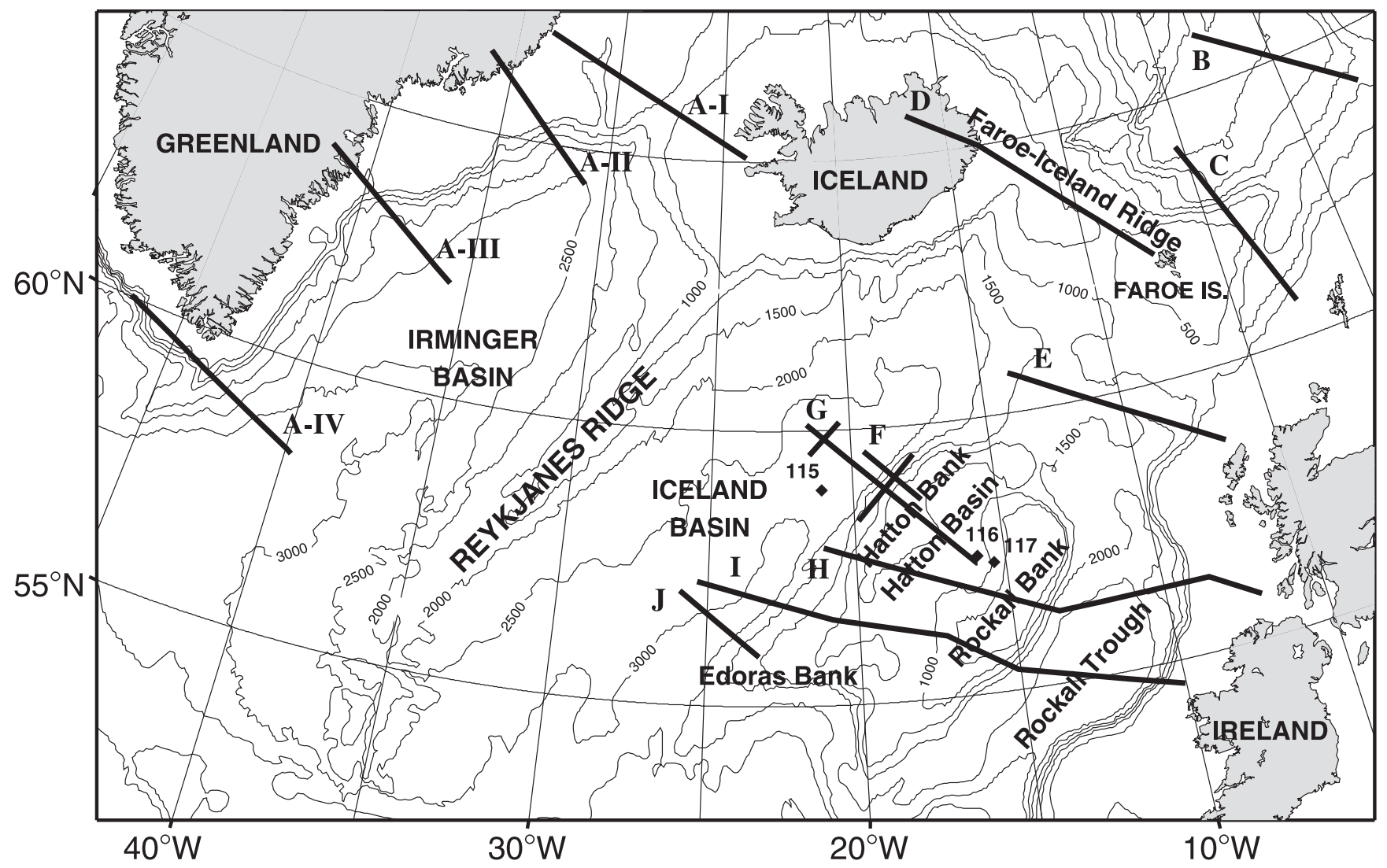

Fig. 1. Location of refraction surveys across the transition from continental to oceanic crust in this region of the northern North Atlantic. Bathymetry contours are in metres. Locations of deep sea drilling project (DSDP) sites 115, 116 and 117 are indicated with diamonds. Lines A-I to A-IV: Seismic imaging of the Greenland Margin project (SIGMA) (Korenaga et al. 2000; Holbrook et al. 2001; Hopper et al. 2003). Line B: Breivik et al. (2003). Lines C and $\mathrm{G}$ are the seismic profiles carried out by iSIMM in June 2002 (White et al. 2002) of which line G is discussed in this paper. Line D: Faroe-Iceland Ridge Experiment (FIRE) (Smallwood et al. 1999). Line E: Atlantic Margin Project Line E (pers. comm. R. Hobbs, see http://bullard.esc.cam.ac.uk/ amp/). Line F: Morgan et al. (1989); Fowler et al. (1989). Line H: Keser Neish (1993). Line I: Rockall and Porcupine Irish deep seismic (RAPIDS) profile (Vogt et al. 1998). Line J: Barton \& White (1997).

paper reports preliminary results from the Hatton Bank survey where data analysis has begun on wide-angle and normalincidence seismic profiles recorded across the hitherto poorly explored Hatton Basin adjacent to the margin.

\section{Geological setting}

Rockall Plateau is a broad region, topographically elevated with respect to the ocean basins. It is isolated from the sedimentary basin systems of the European continental shelf to the east by Rockall Trough and is bounded on the western side by the oceanic Iceland Basin. The region contains a series of basins and banks that trend in a NE-SW direction with Hatton Basin separating Rockall Bank on the eastern side from the smaller topographic highs of Hatton Bank and Edoras Bank on the western edge (Fig. 1). Geological and geophysical studies have established the continental origin of Rockall Plateau. Dredging of Rockall Bank has recovered samples of Precambrian basement petrographically similar to the Lewisian granulites of the Outer Hebrides of Laxfordian age (1600 Ma, Roberts et al. 1973) and Grenvillian age (990 Ma, Miller et al. 1973). Seismic refraction studies (Scrutton 1972; Bunch 1979) have confirmed that the crust below Rockall Bank is continental in both its crustal velocity structure and its thickness (depth to Moho $30-33 \mathrm{~km}$ ). More recent refraction studies in the region (Line H, Fig. 1), constrain the Moho depth to be $15 \mathrm{~km}$ beneath Hatton Basin, interpreted as an area of thinned continental crust (Keser Neish 1993).

The rifting history of Rockall Plateau is complex, showing three major phases. Rifting between Rockall and the European continent began in pre-Cretaceous time along a NE-SW-trending rift
(Cole \& Peachey 1999). The majority of rifting and the subsequent formation of Rockall Basin occurred in mid- to late Cretaceous time, continuing into the Eocene (Cole \& Peachey 1999). This separated the micro-continent of Rockall Plateau from the European continent. The Hatton Basin was created during a period of rifting in the mid-Cretaceous (Smythe 1989) before spreading shifted westward to open the Labrador Sea, splitting the Greenland-Rockall plate from North America (Srivastava 1978). At 57-56 Ma, just prior to magnetic anomaly 24, rifting initiated between Greenland and Rockall (Barton \& White 1997), resulting in the formation of a rifted continental margin along the western flank of Rockall Plateau, including the Hatton Bank margin and the conjugate margin of East Greenland. This margin experienced the influence of the hot mantle from the Iceland plume during rifting, producing abundant igneous activity.

The thin veneer of post-rift sediments provides excellent opportunities to investigate the formation and evolution of the deep crust of the Hatton Bank margin using seismic methods. Our survey is designed to allow us to model the crustal structure of the continental margin and stretched continental crust with improved accuracy in order to constrain lower-crustal velocities and provide quantitative estimates of the amount of melt emplaced in the lower crust and extruded at the surface.

\section{Data acquisition}

\section{Survey layout}

During June-July 2002, the iSIMM project acquired new data from the Hatton Bank region aboard the NERC research vessel 
RRS Discovery using 89 static four-component ocean-bottom seismometers (OBS) and a $2.4 \mathrm{~km}$ multichannel hydrophone streamer as part of a large wide-angle and coincident reflection survey (Fig. 2) (White et al. 2002). Survey parameters are summarized in Table 1.

The $450 \mathrm{~km}$ dip line (Line 5) runs perpendicular to the continental margin from the stretched continental crust of Hatton Basin across Hatton Bank and out onto the oceanic crust of the Iceland Basin. Two strike lines totalling $230 \mathrm{~km}$ length were recorded parallel to the margin, one line (Line 7) above the region of thickest extrusive and intrusive igneous rock on Hatton Bank and the other (Line 3) over $44 \mathrm{Ma}$ oceanic crust near the oceanic end of the main dip profile. The OBS were supplied by GeoPro $\mathrm{GmbH}$ and consisted of gimbal-mounted three-component geophones and a deep-sea hydrophone. A dense OBS spacing of $4 \mathrm{~km}$ was used at the crossover point of the dip and strike lines across the margin and a spacing of $10 \mathrm{~km}$ was used on the outer ends of the lines.

The multichannel seismic (MCS) reflection data were acquired simultaneously with airgun shooting into the OBS to provide reflection seismic constraint on the shallow sediments down to the top basalt or basement surface. In addition, two linking ship transfer lines (Lines 4 and 6) and another dip profile across the continental margin (Line 8) were acquired. A long shooting interval of $150 \mathrm{~m}$ (approximately $60 \mathrm{~s}$ ) was chosen along the OBS profiles in order to reduce the reverberation of seismic energy in the water column which can appear as strong wrap-round or 'previous shot noise' (Nakamura et al. 1987; McBride et al. 1994). The shot interval was reduced to $75 \mathrm{~m}$ (approx. $30 \mathrm{~s}$ ) along the connecting and additional reflection profiles. As profiling was optimised for wide-angle data acquisition the MCS data primarily provide sediment thickness and velocity data. Detailed reflection images of the shallow crust, for example the nature and extent of SDRs, are available from previous reflection profiles in this region (e.g. White et al. 1987; Spence et al. 1989; Barton \& White 1997).

\section{Source design}

In order to image the lower crust in regions such as this, which contain thick basaltic sequences, it is necessary to employ the lowpass transmission response of the basalt sequences by generating a low-frequency source (e.g. Pujol \& Smithson 1991; Mack 1997; Ziolkowski et al. 2001). The low frequencies required to penetrate vertically heterogeneous sequences cannot readily be generated using conventional seismic systems. Interference of the seasurface ghost with the source signal discriminates against low frequencies when the source is towed at conventional shallow depths (typically 5-10 m) (Ziolkowski et al. 2001). The frequency effect of this interference is depth dependent, since increasing the source depth lowers the interference frequency of the signal and enhances the contribution from low frequencies. However, when airguns are towed at greater depth the ambient water pressure increases, which has the effect of causing the dominant oscillation frequency of the airgun bubble to increase. Maximizing the lowfrequency energy of the source therefore requires a compromise between towing the source at greater depths to optimize the interference effects of the ghost and towing at shallower depths to reduce the ambient water pressure, and hence lower the dominant frequency of the guns.

The source used in this survey was a 14-element, peak-tuned, $101.41\left(6340 \mathrm{in}^{3}\right)$ airgun array (Fig. 3). Two large guns (161, $1000 \mathrm{in}^{3}$ ) and a range of smaller gun sizes were towed at $10-20 \mathrm{~m}$ depth to produce a source signature that was much richer in low frequencies than a conventional source (for details of the source

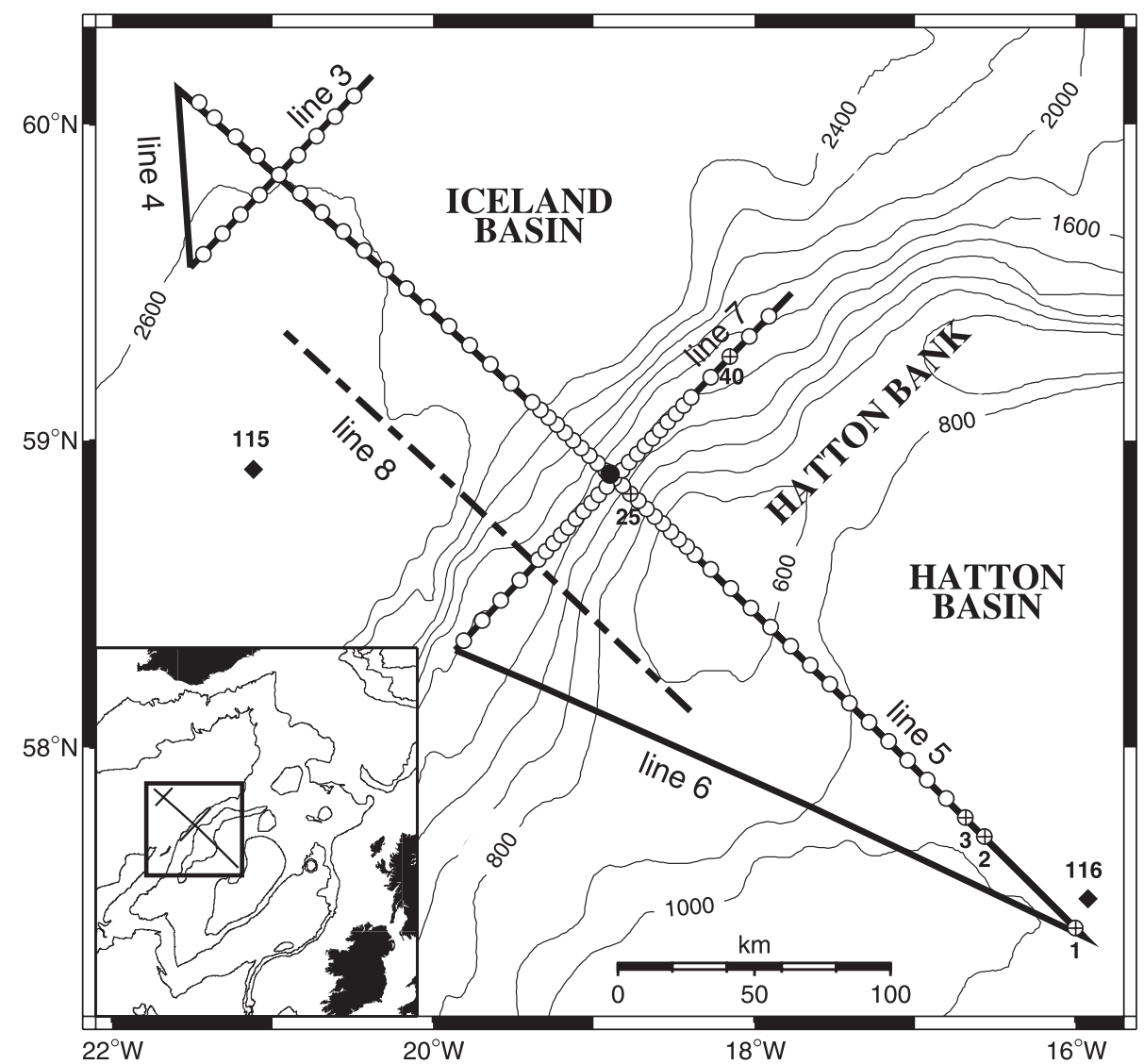

Fig. 2. Layout of normal-incidence and refraction profiles and instrument locations comprising part of the iSIMM project. Broken line indicates additional normal-incidence profile acquired after recovery of ocean-bottom seismometers (OBS). OBS are indicated by open circles. OBS referred to in this paper are numbered and marked by a cross. The filled circle shows the location of the vertical hydrophone array used for source signature monitoring. DSDP drill sites 115 and 116 are shown by diamonds. 
Table 1. Summary of survey parameters

\begin{tabular}{|c|c|}
\hline \multicolumn{2}{|l|}{ RRS Discovery } \\
\hline Navigation & Differential GPS \\
\hline \multicolumn{2}{|l|}{ Source } \\
\hline Total gun volume & $101.41\left(6340 \mathrm{in}^{3}\right)$ \\
\hline Guns & Bolt $1500 \mathrm{LL}$ \\
\hline Number of guns & 14 \\
\hline Tuning & Peak tuned \\
\hline Pressure & 140 bar \\
\hline Frequency Range & $2-44 \mathrm{~Hz}$ \\
\hline Shot interval & $75-150 \mathrm{~m}$ \\
\hline Source depth & $10-20 \mathrm{~m}$ \\
\hline Signature monitoring & $\begin{array}{l}\text { deep-water vertical } \\
\text { hydrophone array }\end{array}$ \\
\hline \multicolumn{2}{|l|}{ Streamer } \\
\hline Streamer length & $2400 \mathrm{~m}$ \\
\hline Receivers & 96 at $25 \mathrm{~m}$ receiver interval \\
\hline Streamer depth & $18 \mathrm{~m}$ \\
\hline $\begin{array}{l}\text { Distance from source to } \\
\text { first channel }\end{array}$ & $193 \mathrm{~m}$ \\
\hline Maximum offset & $2568 \mathrm{~m}$ \\
\hline Sample rate & $4 \mathrm{~ms}$ \\
\hline Record length & $15 \mathrm{~s}$ \\
\hline Fold & 8 \\
\hline \multicolumn{2}{|c|}{$\begin{array}{l}\text { Ocean-bottom seismometers - } \\
\text { digital OBS }\end{array}$} \\
\hline Receivers & $\begin{array}{l}\text { three-component } \\
\text { geophone }+ \text { hydrophone }\end{array}$ \\
\hline Type & SEDIS III \& SEDIS IV \\
\hline Eigen frequency & $4.5 \mathrm{~Hz}$ \\
\hline Sample rate & $4 \mathrm{~ms}$ \\
\hline Recording & $\begin{array}{l}\text { Continuously recording } \\
\text { for } 14 \text { days }\end{array}$ \\
\hline
\end{tabular}

design see Lunnon et al. 2003). A vertical hydrophone array was deployed in deep water at the centre of the survey area (filled circle, Fig. 2) to record the far-field source waveform. Approximately $300 \mathrm{~ms}$ of the down-going signature was recorded before the arrival of the water bottom reflection (Fig. 4a). The peak-topeak amplitude of the waveform is 74 bar-m and the spectrum of the source signature (Fig. 4b) shows that there is considerable lowfrequency energy down to $5 \mathrm{~Hz}$. The peak output is at $10 \mathrm{~Hz}$ and the overall shape is relatively flat up to the ghost notch at $44 \mathrm{~Hz}$.

\section{Processing}

\section{Multichannel seismic data}

Conventional processing techniques were applied to the MCS reflection data from the dip line (Line 5) to produce a stacked profile (Fig. 5). After $10-50 \mathrm{~Hz}$ band-pass filtering, sphericaldivergence correction and predictive deconvolution, velocity analysis was carried out with CMP supergathers (i.e. five adjacent CMP gathers summed together). Due to the low fold of the data (eight-fold), which was necessary to minimize 'wrap-round' noise

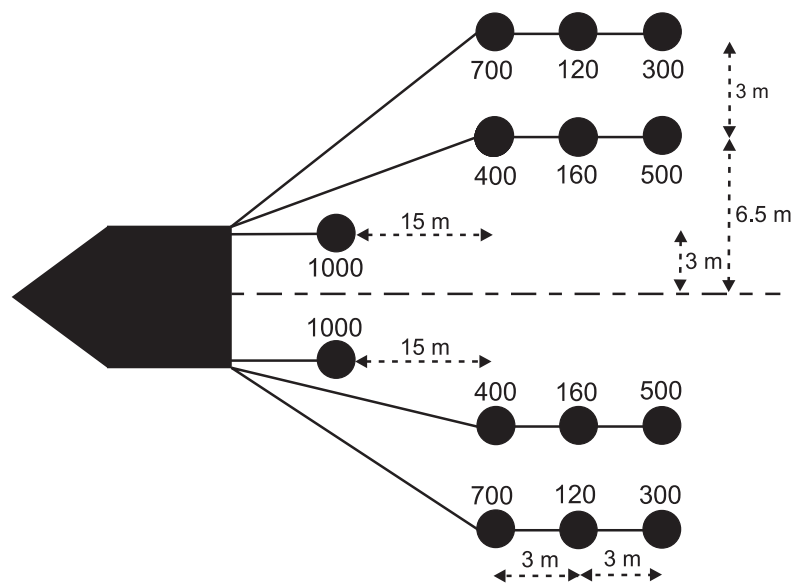

Fig. 3. The symmetric 14-element airgun array used in data acquisition (total volume $101.41,6340 \mathrm{in}^{3}$ ). All guns were Bolt $1500 \mathrm{LL}$ fired at 2000 psi. Gun volumes are annotated in cubic inches. The two large guns $\left(161,1000 \mathrm{in}^{3}\right)$ were towed at $10 \mathrm{~m}$ depth and the smaller guns were towed at $20 \mathrm{~m}$ depth.

on the wide-angle data, the CMP gathers were f-x interpolated to enhance the signal-to-noise ratio in the final stack. In addition to strong seafloor and top basalt or basement reflections, several strong sedimentary reflections were available to calculate stacking velocities.

\section{Wide-angle seismic data}

The data acquired from the OBS are of excellent quality and require minimal processing to enhance the arrivals. The positions of the OBS on the seafloor were found approximately from the GPS deployment location, which was refined by triangulation using well-determined water waves. The actual position on the sea floor differs from deployment position by up to $400 \mathrm{~m}$ due to ocean
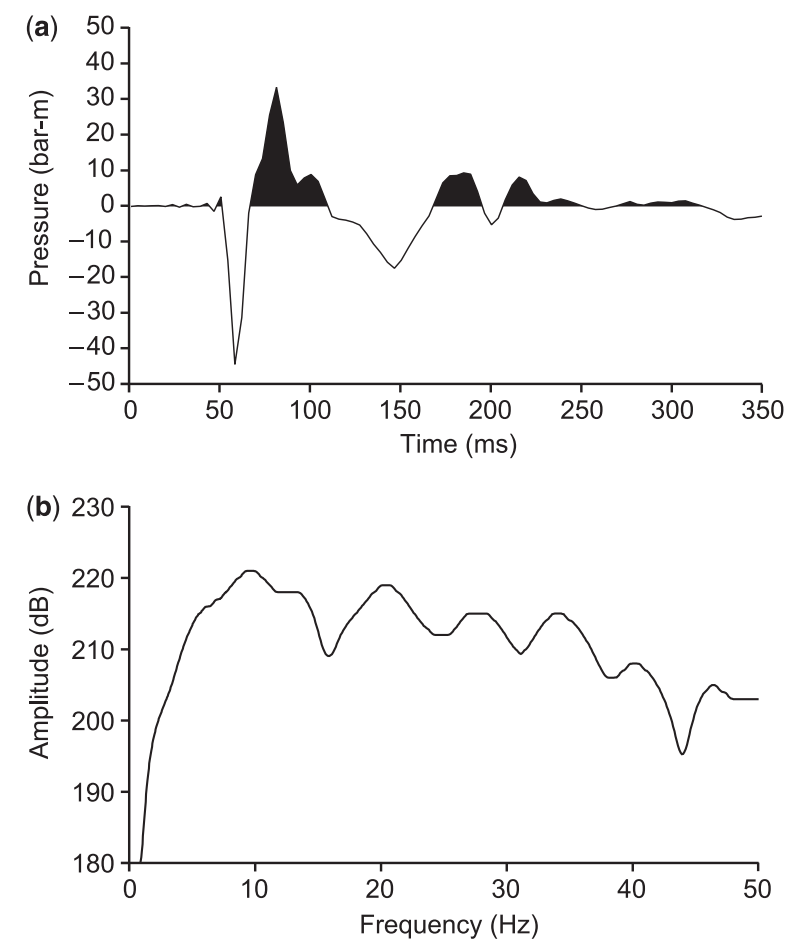

Fig. 4. (a) Signature generated by the 14-element $101.41\left(6340 \mathrm{in}^{3}\right)$ airgun source used during data collection recorded using the vertical hydrophone array (Fig. 2). Peak-to-peak amplitude is 74 bar-m; (b) Spectrum of the source signature in (a). Peak output is at approximately $10 \mathrm{~Hz}$. 


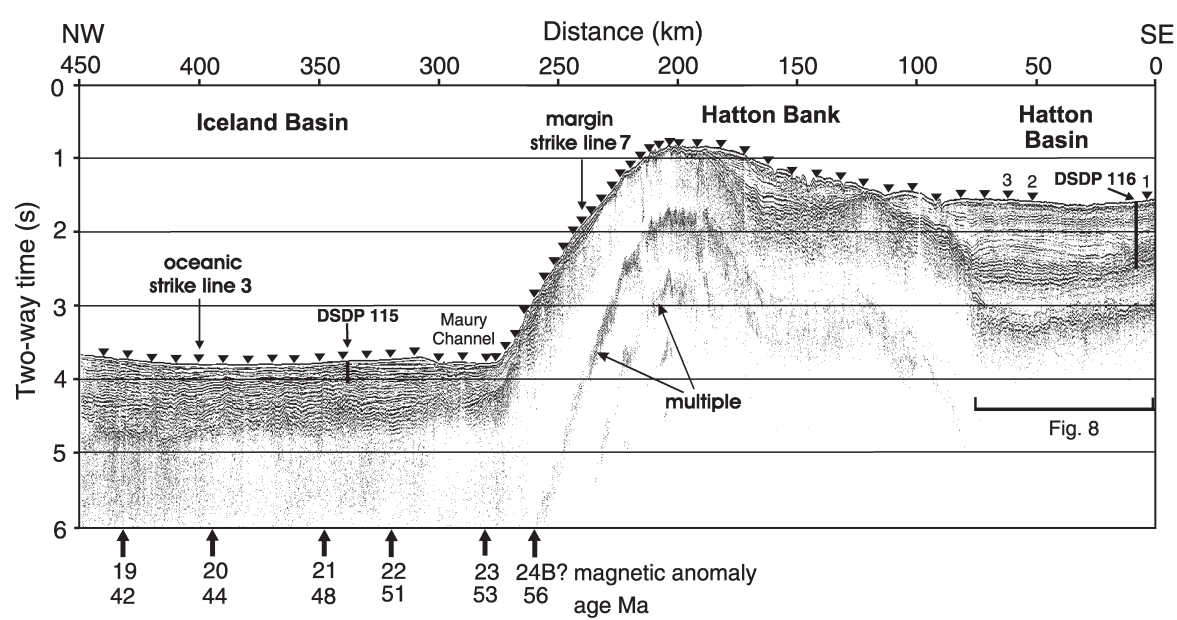

Fig. 5. Stack of MCS reflection data acquired along Line 5 (dip line). Inverted triangles indicate OBS position along the profile. The cross-line positions of the margin and oceanic strike lines are indicated. Approximate locations of positive magnetic anomalies observed in the oceanic crust of the Iceland Basin are shown with corresponding age (from Smallwood \& White 2002). The relative depths of DSDP drill sites (115\&116) close to the reflection dip profile are shown.

current drift. In addition, the data were band-pass filtered from $2-18 \mathrm{~Hz}$ to allow manual picking of first arrivals and clear secondary arrivals.

Figures 6 and 7 show examples of data recorded by OBS above the Hatton Bank margin and illustrate the effect of varying bathymetry on the wide-angle arrivals which can be seen at offsets of up to $140 \mathrm{~km}$. Strong arrivals are observed from clear crustal diving waves $(\mathrm{Pg})$ and reflections from the crust-mantle boundary (Moho reflection, PmP). Figure 7 also shows a mantle refraction arrival (Pn) recorded on OBS 40 along the margin strike line, which provides velocity information on the mantle beneath the margin (velocities in the range $7.8-7.9 \mathrm{~km} / \mathrm{s}$ ).

\section{Velocity modelling}

Travel-time modelling has been carried out on three OBS from the southeastern end of the dip line (OBS $1-3$, Fig. 2) in order to constrain the large-scale velocity structure and new estimates of crustal thickness in this hitherto poorly explored region. Measurements of sediment thickness and velocity variations from the MCS profile were used as a starting point for ray-trace modelling of the vertical-component geophone data from the OBS (Fig. 8). The reflectors observed on the MCS reflection data are consistent with results from a site survey for DSDP sites 116 and 117 (Laughton et al. 1972), and we use the same reflector numbering system as Roberts et al. (1970). The multichannel reflection data imaged a series of sub-horizontal layered sediments in the upper part of the basin which onlap a strong reflector (reflector 4) observable across the western side of the basin, which becomes more diffuse towards the east (Fig. 8). Reflector 4 unconformably overlies a seismically transparent layer whose base is defined by a strong irregular reflector (reflector 5), which is the deepest reflector visible on the section. Conventional velocity analysis of the data shows that the average velocities of the different layers vary little at a given depth below the seafloor across the basin. The upper horizontally layered sediments down to $2.35 \mathrm{~s}$ TWT exhibit average velocities of $1.7-2.5 \mathrm{~km} / \mathrm{s}$. Reflector 4 marks the lower boundary of strong horizontally layered sediments below $2.35 \mathrm{~s}$ TWT, which exhibit higher velocities in the range $3.0-3.5 \mathrm{~km} / \mathrm{s}$ across the basin. A velocity inversion is observed in

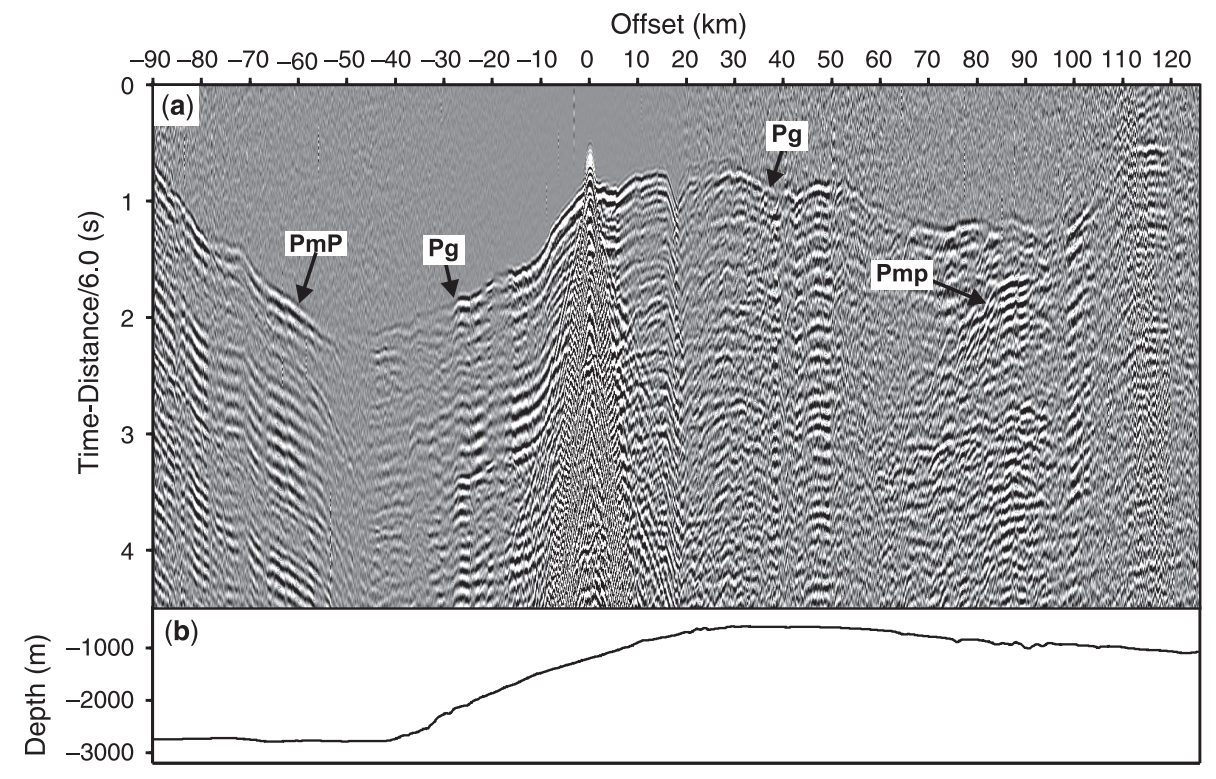

Fig. 6. (a) Observed seismic section from the vertical geophone component of OBS 25 located on Line 5 (see Fig. 2) on the flank of Hatton Bank. The data have been band-pass filtered from $2-18 \mathrm{~Hz}$, trace balanced and a reduction velocity of $6 \mathrm{~km} / \mathrm{s}$ has been applied for display. Pg, refraction from crystalline basement; PmP, Moho reflection; (b) Bathymetry along Line 5 in the region of data recorded on OBS 25. 


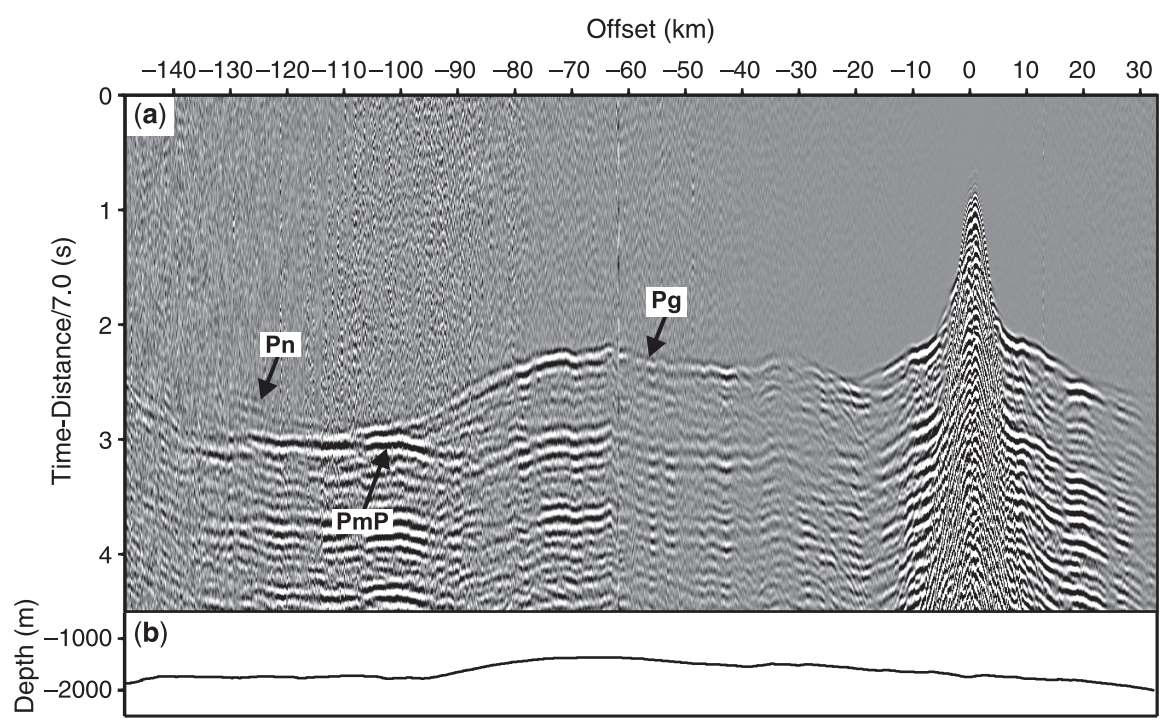

Fig. 7. (a) Observed seismic section from the vertical geophone component of OBS 40 located on the northern end of the margin strike line (Line 7; see Fig. 2). The data have been band-pass filtered from $2-18 \mathrm{~Hz}$, trace balanced and a reduction velocity of $7 \mathrm{~km} / \mathrm{s}$ has been applied for display. Pg, refraction from crystalline basement; PmP, Moho reflection; Pn, Mantle refraction; (b) Bathymetry along Line 7 in the region of data recorded on OBS 40.

the transparent sediments below reflector 4 . However, at this depth the velocities were difficult to determine accurately using conventional velocity analysis of the reflection data. The velocity structure between reflectors 4 and 5 was further constrained by wide-angle data and the velocity structure deeper than reflector 5 was mapped by ray-trace modelling of the wide-angle data alone, using a forward ray-tracing program for two-dimensionally varying structure (Zelt \& Smith 1992).

The most prominent arrivals observed on the record sections from OBS 3 located in the Hatton Basin are labelled on Figure 9. The velocities obtained from the shallow sediment arrivals on the wide-angle data agree well with the velocities observed in the refraction data. Sediment refraction $S_{1}$ is associated with the strong horizontal reflectors observed on the MCS section bounded beneath by reflector 4 (Fig. 8). The strong secondary arrivals of the reflection labelled $\mathrm{S}_{2}$ correspond to the deepest of reflectors (reflector 5) observed on the multichannel reflection data (Fig. 8). The lowvelocity zone observed in the MCS data can be seen on the wideangle section from OBS 3 (Fig. 9) with the termination of refraction $S_{1}$ and the step back to reflection $S_{2}$ at approximately $7 \mathrm{~km}$ offset. Refraction arrivals at the OBS show velocities in the layer beneath the strong rugged reflector (reflector 5) in the range $4.5-4.8 \mathrm{~km} / \mathrm{s}$ (arrival $S_{3}$, Fig. 9). Arrival $S_{3}$ is interpreted as a diving wave from the top of the crystalline basement. This event is only observed out to $25 \mathrm{~km}$ offset due to the low signal-to-noise ratio beyond this distance, which limits identification of any refractions from midcrustal horizons that may be present (Fig. 9). Figure 10 shows the ray coverage diagram for the model determined from the MCS data and the wide-angle data from OBS 2 and 3 for the sediments in the western end of the Hatton Basin.

The absence of any mid-crustal refractions in these data from the Hatton Basin allows only limited constraint on the velocity structure and the velocity gradient in the crust and therefore greater uncertainty in calculation of depth to Moho. With greater OBS coverage to the west of the basin across the Hatton Bank margin it is hoped to gain more constraint on the velocity structure within the stretched continental crust and to more accurately constrain depth to Moho in that area. The reflection from the crust-mantle boundary (PmP) across Hatton Basin is first recognised at an offset of around $52 \mathrm{~km}$, as the amplitudes increase toward the critical distance for Moho reflection and enables us to estimate the depth to the Moho in this section of the Hatton Basin.

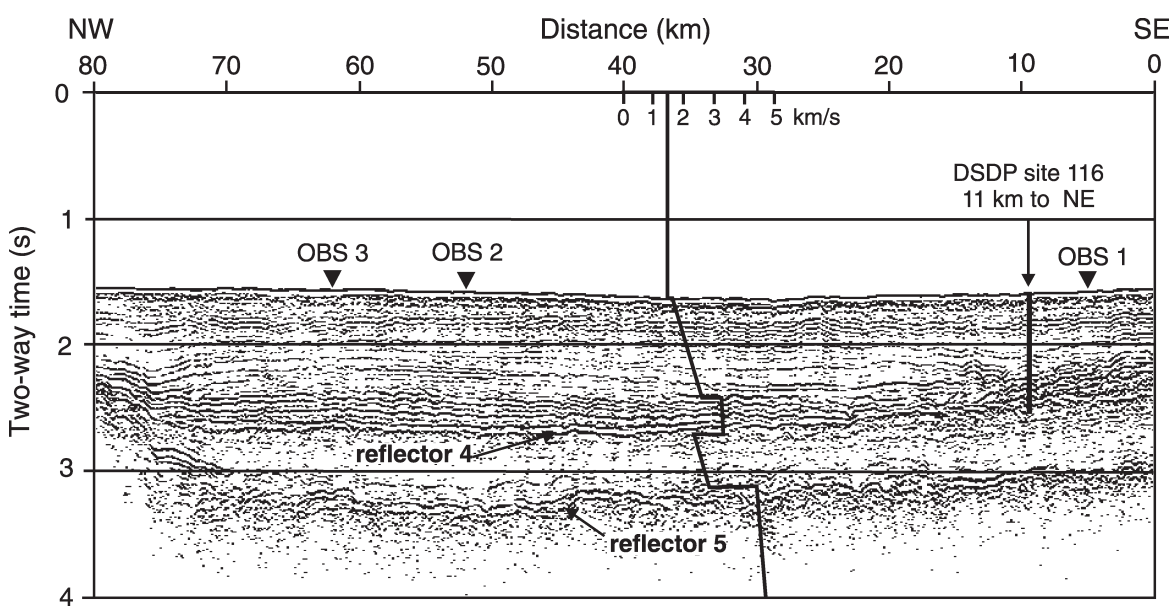

Fig. 8. Stack of the multichannel reflection data acquired across the Hatton Basin section of Line 5 (see Fig. 5 for location). Reflector numbering matches that used by Roberts et al. (1970). OBS deployed in the basin are indicated by inverted triangles. The relative position and depth penetrated by the DSDP site 116 located $11 \mathrm{~km}$ to the NE of the seismic line is shown. Interval velocities derived from velocity analysis of both MCS and wide-angle data are superimposed at $40 \mathrm{~km}$. 


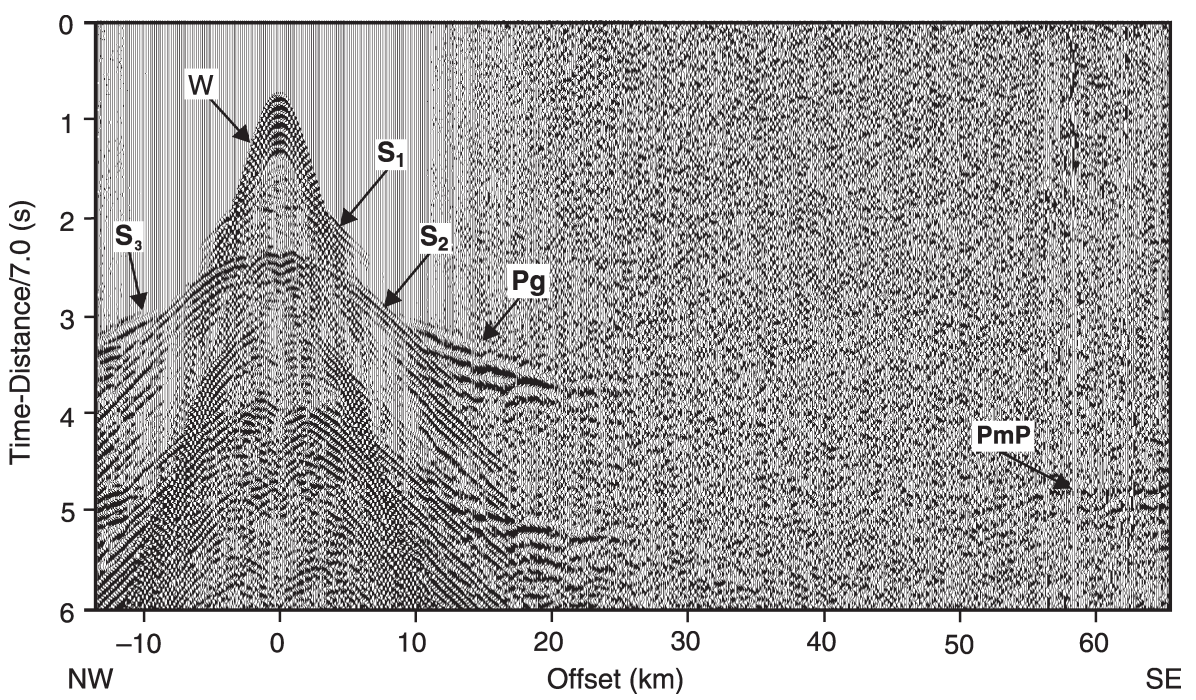

Fig. 9. Observed seismic section from the vertical geophone component of OBS 3 located within Hatton Basin. The data have been band-pass filtered from $2-18 \mathrm{~Hz}$, trace balanced and a reduction velocity of $7 \mathrm{~km} / \mathrm{s}$ has been applied for display. W, water wave; $\mathrm{S}_{1}$, refraction from the sediment layer whose base is defined by reflector 4 (see Fig. 8); $\mathrm{S}_{2}$, reflection from reflector $5 ; \mathrm{S}_{3}$, refraction from older sediment succession; Pg, refraction from crystalline basement; PmP, Moho reflection.

\section{Interpretation}

\section{Multichannel seismic data}

The MCS reflection data collected along Line 5 have imaged the major sedimentary features of this region and the broad structure of Hatton Bank rising from the edge of Hatton Basin in the southeast and descending toward the deep ocean basin to the northwest (Fig. 5). Since the plateau is separated from the sedimentary systems of western Ireland by the Rockall Trough, sedimentation in the region is dominated by both contour currents associated with the outflow of Norwegian Sea water southwards over the Faroe-Iceland Ridge (Roberts 1975) and contour currents within the Iceland Basin flowing north along the western flank of Rockall Plateau (McCave et al. 1980). In addition, the region is influenced by turbidity currents that flow southward from Iceland along the Maury Channel (McCave et al. 1980), which is clearly visible on the multichannel section at the foot of the continental slope (Fig. 5).

The results from DSDP site 116, which lies approximately $11 \mathrm{~km}$ to the northeast of the main dip line (Fig. 2) and sampled the basin-fill sediments to a depth of $853 \mathrm{~m}(\sim 2.5 \mathrm{~s}$ TWT) below the sea floor (Fig. 8) (Laughton et al. 1972) have been used to interpret the MCS data from the Hatton Basin. The upper horizontally layered sediments are Miocene and PliocenePleistocene calcareous oozes deposited without interruption as fallout from a bottom current flowing southward between Hatton and Rockall banks (Laughton et al. 1972). Reflector 4 is a major boundary between the horizontally bedded sediments above and the transparent sediments below. At site 116, this forms a diffuse reflector associated with lithified sediment, hard chalk and chert, accumulated in depressions of an unconformity between Upper and Lower Oligocene sediments. The unconformity marks a hiatus in deposition ranging from around $7 \mathrm{Ma}$ in the centre of the basin to $20 \mathrm{Ma}$ at the basin edges (Laughton et al. 1972). DSDP site $117,33 \mathrm{~km}$ to the east of Line 5, penetrated the transparent sediment layer beneath reflector 4 and found dense grey clay of lower Eocene and Upper Paleocene age with a high terrigenous content. The borehole sampled a basaltic basement that is vesicular in nature, which together with the terrigenous content of the overlying clays indicates a shallow water environment of extrusion

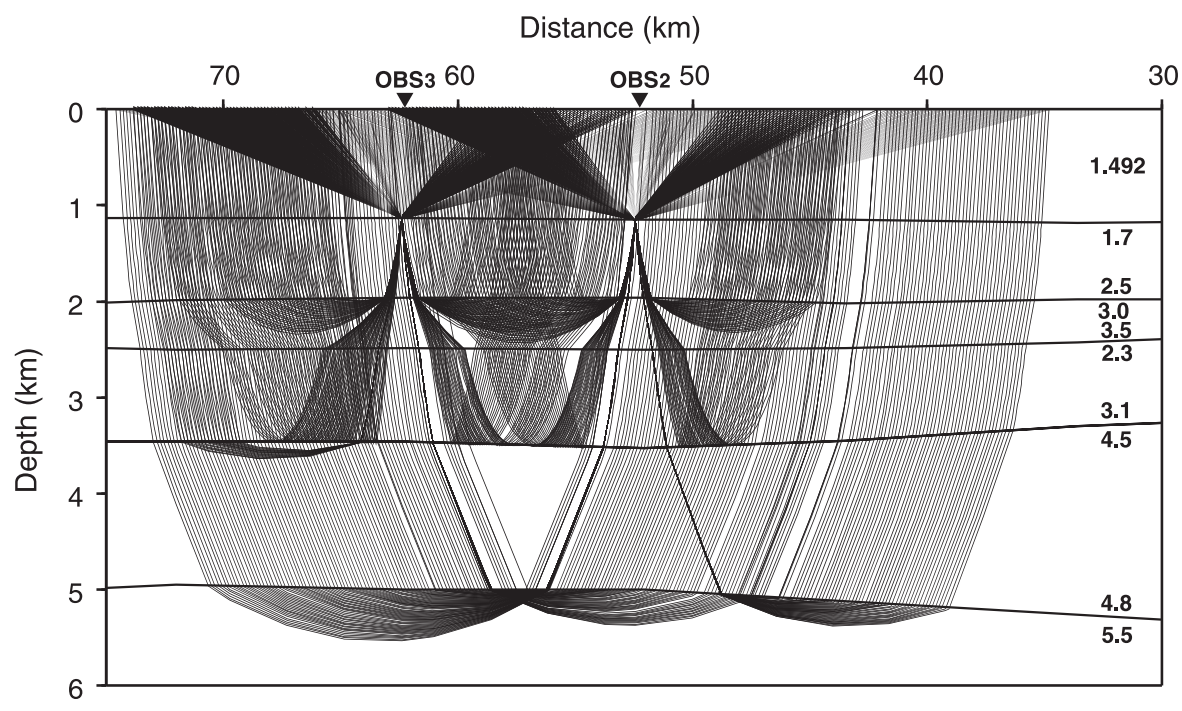

Fig. 10. Ray coverage diagram for sediment and crustal arrivals from OBS 2 and 3, modelled for the western end of the Hatton Basin using the forward ray-tracing program RAYINVR. Velocities modelled at the top and bottom of the layers are shown in $\mathrm{km} / \mathrm{s}$. 
and subsequent sedimentation (Laughton et al. 1972). However, there was inadequate data to correlate the strong rugged reflector beneath Hatton Basin with this drilled basement (Laughton et al. 1972).

\section{Wide-angle data: Hatton Basin}

The results of modelling the wide-angle arrivals are consistent with the results from the multichannel reflection data. Sediment refraction $S_{1}$ is associated with the higher velocity layer bounded beneath by reflector 4 correlating to the hard chalks and cherts drilled at DSDP sites 116 and 117. The strong secondary arrivals of the reflection labelled $S_{2}$ correspond to reflector 5 observed on the multichannel reflection data. This reflection event on the wideangle sections allowed velocities for the low velocity layer to be estimated to lie in the range $2.3-3.1 \mathrm{~km} / \mathrm{s}$. Modelling the refraction data from the OBS shows that reflector 5 beneath Hatton Basin is the upper boundary of a layer with velocities in the range $4.5-4.8 \mathrm{~km} / \mathrm{s}$, suggesting that it is associated with another sedimentary sequence rather than the vesicular basalt which was sampled at the base of site 117. These results are consistent with the results of Vogt et al. (1998) whose surveys across Hatton Basin lie to the south of this survey (Line I, Fig. 1). Vogt et al. (1998) found the Hatton Basin to consist of a two-layer sedimentary sequence with the upper layer having a thickness of $1.0-2.5 \mathrm{~km}$ and a velocity of $\sim 2 \mathrm{~km} / \mathrm{s}$ and the lower layer up to $3.5 \mathrm{~km}$ thick with velocities in the range $4.2-4.6 \mathrm{~km} / \mathrm{s}$. The lower sedimentary layer was interpreted to be an older syn-rift sedimentary succession because the present day depth of burial of the sediments was insufficient to explain the strong velocity contrast between the two layers (Vogt et al. 1998).

From the new data collected in the Hatton Basin an average thickness of $2.1 \pm 0.5 \mathrm{~km}$ was determined for the upper sediments in the basin from the MCS reflection data down to reflector 5 and results from the wide-angle data showed the underlying older sedimentary sequence to have an average thickness of $2.0 \pm 0.5 \mathrm{~km}$. Total sediment thickness in the basin is therefore $\sim 4 \mathrm{~km}$. The depth to the Moho was calculated as $19 \pm 2 \mathrm{~km}$ (Fig. 11), the uncertainty being due to the lack of mid-crustal refractions which would have allowed the lower crustal velocity to be constrained more accurately. This initial estimate for Moho depth provided a crustal thickness excluding sediments of 15$16 \mathrm{~km}$, which again is consistent with the results of Vogt et al. (1998). Crustal models previously determined for Rockall Bank (Bunch 1979; Vogt et al. 1998) resolved crustal thickness to be approximately $30 \mathrm{~km}$. A decrease in crustal thickness from $30 \mathrm{~km}$ under Rockall Bank to $15-16 \mathrm{~km}$ under Hatton Basin gives a crustal stretching factor of $\sim 2$.

\section{Discussion}

The new results from this paper are shown, together with the velocity structure of the Hatton Bank margin (Fig. 11) determined from the results of a 1986 survey located $30 \mathrm{~km}$ to the north of Line 5 (Line F, Fig. 1; Fowler et al. 1989; Morgan et al. 1989). The velocity structure between Hatton Basin and the axis of Hatton Bank (i.e. between the new results of this paper and those of Morgan et al. 1989) have been interpolated and are indicated by broken lines. Figure 11 also shows these results integrated with results from the approximately conjugate location on the Greenland margin from the Seismic Imaging of Greenland Margins (SIGMA) project (Line A-III, Fig. 1: Hopper et al. 2003).

The model of Morgan et al. (1989) (Fig. 11) shows the deep crustal structure beneath the margin to be characterized by elevated velocities $(7.3-7.4 \mathrm{~km} / \mathrm{s})$. These high velocities are interpreted to be caused by the underplating of new material and/or the mixture of old continental crust, upper mantle and new accreted material (Morgan et al. 1989). In addition, the oceanic crust in the adjacent ocean basin (11 km thick, west of anomaly 24$)$ is thicker than normal oceanic crust generated away from the influence of a mantle plume (typically $7 \mathrm{~km}$, White 1992). With the extensive dataset collected from our survey we will be able to model the velocity structure between Hatton Basin and the axis of Hatton Bank and compare the new data to the established model for the continental margin.

Hopper et al. (2003) carried out a comparison of the two conjugate margins using data from the East Greenland margin and the previous results for the Hatton Bank margin from Fowler et al. (1989); Morgan et al. (1989). The SIGMA III transect lies approximately $100 \mathrm{~km}$ to the north of the conjugate margin position of Line 5. Figure 11 shows the data from the two margins merged at the approximate position of magnetic anomaly 22 (51 Ma), which is several million years after the onset of seafloor spreading. The principal difference between the two margins is the obvious asymmetry. There is evidence for unusually high velocities in the lower crust $(>7.3 \mathrm{~km} / \mathrm{s})$ on both sides. However, the asymmetry is apparent in the relative horizontal length scale of the continent-ocean transition (COT) on each margin (Hopper et al. 2003). On Hatton Bank the igneous crustal thickness decreases from 18 to $11 \mathrm{~km}$ after only $50-60 \mathrm{~km}$ of sea-floor spreading, compared to a similar decrease in igneous crustal thickness over $120 \mathrm{~km}$ of seafloor spreading on the Greenland margin (Hopper et al. 2003).

Future processing and modelling of the extensive dataset collected by iSIMM in 2002 will provide further results from the stretched continental crust beneath Hatton Basin through to the fully oceanic crust of the Iceland Basin. These new results can be used to improve the accuracy of established crustal models from this area and to enhance the comparison with the conjugate margin

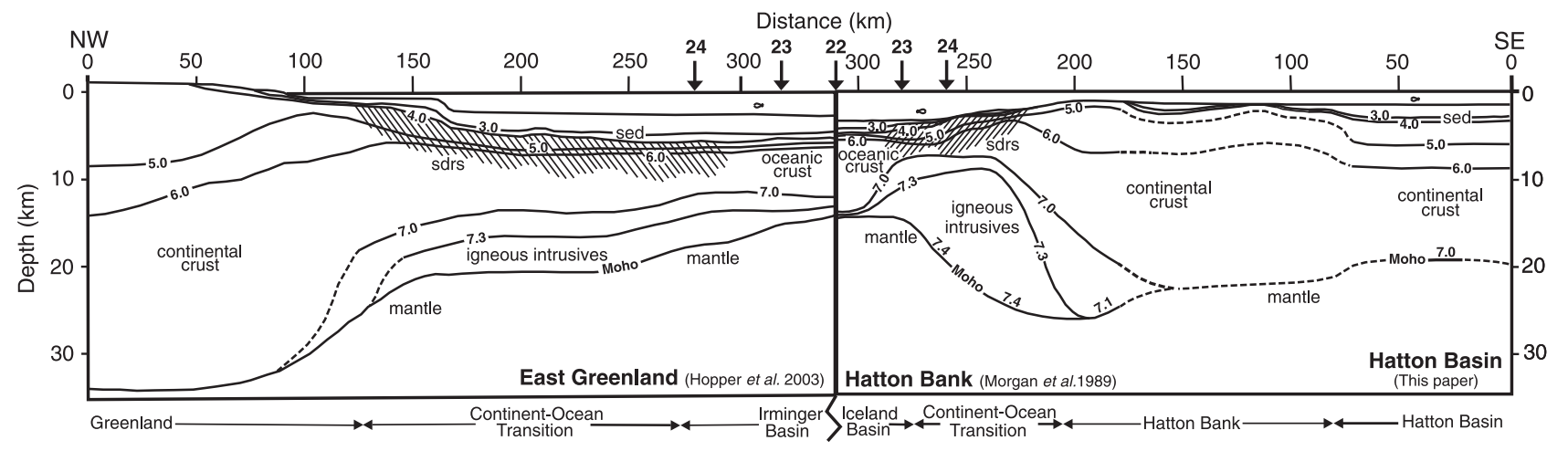

Fig. 11. Integrated results of the modelling outlined in this paper and those determined from the previous study of the region by Fowler et al. (1989); Morgan et al. (1989) and from the conjugate East Greenland margin SIGMA III (Hopper et al. 2003). Arrows along the top axis indicate positions of seafloor magnetic anomalies along both profiles. 
of East Greenland. An improved estimate of crustal structure will allow quantitative calculations of the amount of melt emplaced in the lower crust and extruded at the surface, furthering our understanding of the influence of the Iceland plume on continental break-up, and therefore providing insight to the formation and evolution of the Hatton Bank continental margin.

\section{Conclusions}

The survey design used by the iSIMM project in the acquisition of new data from the Hatton Bank region has been successful in providing a large new dataset of excellent quality wide-angle data. The low-frequency source, centred at $10 \mathrm{~Hz}$, used during acquisition allowed seismic energy to penetrate the complicated upper crust and sample the lower crust and upper mantle to ranges of up to $140 \mathrm{~km}$, which has hitherto proved problematic for conventional seismic investigation of volcanic margins.

Initial modelling results from Hatton Basin have provided new estimates of velocity structure and crustal thickness in this region. The basin contains a $\sim 4 \mathrm{~km}$ thick sedimentary sequence consisting of both syn-rift and post-rift sediments, of which the upper $850 \mathrm{~m}$ can be correlated to DSDP site 116. A sub-sediment crustal thickness of $\sim 15 \mathrm{~km}$ was established, which suggests a stretching factor of two relative to the $30 \mathrm{~km}$ thick continental crust under the adjacent Rockall Bank.

The iSIMM project is supported by Liverpool and Cambridge Universities, Schlumberger Cambridge Research, Badley Technology Limited, WesternGeco, Agip, Amerada Hess, Anadarko, BP, Conoco, Phillips, Statoil, Shell, the Natural Environment Research Council (NERC) and the Department of Trade and Industry. It is a part of the NERC's Ocean Margins LINK programme, which seeks to foster collaboration between academia and industry. We are grateful to the master and crew of the RRS Discovery for their efforts in making the acquisition successful. The OBS were provided by GeoPro GmbH. University of Cambridge contribution number ES.7648.

\section{References}

Barton, A. J. \& White, R. S. 1997. Volcanism on the Rockall continental margin. Journal of Geophysical Research, 102(B2), 3109-3129.

Breivik, A. J., Mjelde, R., Raum, T., Shimamura, H. \& Murai, Y. 2003. Tectono-magmatic development of the Moere Margin and adjacent oceanic basin, Norway, derived from OBS data, 10th International Symposium on Deep seismic profiling of the continents and their margins, Seismix 2003 Conference Abstracts.

Bunch, A. W. H. 1979. A detailed seismic structure of Rockall Bank $\left(55^{\circ} \mathrm{N}\right.$ $\left.15^{\circ} \mathrm{W}\right)$ : A synthetic seismogram analysis. Earth and Planetary Scientific Letters, 35, 453-463.

Cole, J. E. \& Peachey, J. 1999. Evidence for pre-Cretaceous rifting in the Rockall Trough: an analysis using quantitative plate tectonic modelling. In: Fleet, A. J. \& Boldy, S. A. R. (eds) Petroleum Geology of Northwest Europe: Proceedings of the 5th Conference. Geological Society, London, 359-370.

Eldholm, O. \& Grue, K. 1994. North Atlantic volcanic margins: Dimensions and production rates. Journal of Geophysical Research, 99, 2955-2968.

Eldholm, O., Thiede, J. \& Taylor, E. 1989. Evolution of the Vøring volcanic margin. In: Eldholm, O., Thiede, J. \& Taylor, R. et al. (eds) Proceedings of the Ocean Drilling Program, Scientific Results, College Station, TX (Ocean Drilling Program), 104, 1033-1065.

Fowler, S. R., White, R. S., Spence, G. D. \& Westbrook, G. K. 1989. The Hatton Bank continental margin II. Deep structure from two-ship expanding spread seismic profiles. Geophysical Journal, 96, 295-309.

Hinz, K. 1981. A hypothesis on terrestrial catastrophes: wedges of very thick ocean ward dipping layers beneath passive margins: their origin and paleoenvironmental significance. Geologisches Jahrbuch Reihe, E22, $3-28$.
Holbrook, W. S., Larsen, H. C., Korenaga, J., Dahl-Jenson, T., Reid, I. D., Kelemen, P. B., Hopper, J. R., Kent, G. M., Lizarralde, D., Bernstein, S. \& Detrick, R. S. 2001. Mantle thermal structure and active upwelling during continental breakup in the North Atlantic. Earth and Planetary Science Letters, 190, 251-266.

Hopper, J. R., Dahl-Jensen, T., Holbrook, W. S., Larsen, H. C., Lizarralde, D., Korenaga, J., Kent, G. M. \& Kelemen, P. B. 2003. Structure of the SE Greenland margin from seismic reflection and refraction data: Implications for nascent spreading center subsidence and asymmetric crustal accretion during North Atlantic opening. Journal of Geophysical Research, 108(B5), 2269-2291.

Keser Neish, J. 1993. Seismic structure of the Hatton area: an integrated seismic/modelling study from composite datasets. In: Parker, J. R. (ed.) Petroleum Geology of Northwest Europe: Proceedings of the 4th Conference. Geological Society, London, 1047-1056.

Korenaga, J., Holbrook, W. S., Kent, G. M., Kelemen, P. B., Detrick, R. S., Larsen, H. C., Hopper, J. R. \& Dahl-Jensen, T. 2000. Crustal structure of the southeast Greenland margin from joint refraction and reflection seismic tomography. Journal of Geophysical Research, 105, 21591-21614.

Larsen, H. C. \& Saunders, A. D. 1994. Tectonism and volcanism at the southeast Greenland rifted margin: a record of plume impact and later continental rupture. Proceedings of the Ocean Drilling Program, Initial Reports. College Station, TX (Ocean Drilling Program), 152, 503-533.

Laughton, A. S., Berggren, W. A., Benson, R., Davies, T. A., Franz, U., Musich, L., Perch-Nielsen, K., Ruffman, A., van Hinte, J. E. \& Whitmarsh, R. B. 1972. Initial reports of the Deep Sea Drilling Project, Volume XIII. 395-671 U.S. Government Printing Office, Washington.

Lunnon, Z., Christie, P. A. F. \& White, R. S. 2003. An evaluation of peak and bubble tuning in sub-basalt seismology: modelling and results. First Break, 21, 51-56.

Mack, H. 1997. Seismic response of Tertiary basalt flows in the Northeast Atlantic - A modelling study: EAGE 59th Conference and Technical Exhibition, Expanded Abstracts, Geneva, Paper B017.

McBride, J. H., Henstock, T. J., White, R. S. \& Hobbs, R. W. 1994. Seismic reflection profiling in deep water: avoiding spurious reflectivity at lower-crustal and upper-mantle traveltimes. Tectonophysics, 232, $425-435$.

McCave, I. N., Lonsdale, P. F., Hollister, C. D. \& Gardiner, W. D. 1980. Sediment transport over the Hatton and Gardar contourite drifts. Journal of Sedimentary Petrology, 50, 1049-1062.

Miller, J. A., Roberts, D. G. \& Matthews, D. H. 1973. Rocks of Greenville age from Rockall Bank. Nature, 246, 61.

Mjelde, R., Sellevoll, M. A., Shimamura, H., Iwasaki, T. \& Kanazawa, T. 1992. A crustal study off Lofoten, N. Norway, by use of 3-component Ocean Bottom Seismographs. Tectonophysics, 212, 269-288.

Morgan, J. V., Barton, P. J. \& White, R. S. 1989. The Hatton Bank continental margin-III. Structure from wide-angle OBS and multichannel seismic refraction profiles. Geophysical Journal International, 98, 367-384.

Mutter, J. C., Talwani, M. \& Stoffa, P. L. 1984. Evidence for a thick oceanic crust adjacent to the Norwegian Margin. Journal of Geophysical Research, 89, 483-502.

Nakamura, Y., Donoho, P. L., Roper, P. H. \& McPherson, P. M. 1987. Largeoffset seismic surveying using ocean bottom seismograms and airguns: Instrumentation and field technique. Geophysics, 52, 1601-1611.

Pujol, J. \& Smithson, S. B. 1991. Seismic wave attenuation in volcanic rocks from VSP experiments. Geophysics, 56, 1441-1455.

Richardson, K. R., White, R. S., England, R. W. \& Fruehn, J. 1999. Crustal structure east of the Faroe Islands. Petroleum Geoscience, 5, 161-172.

Roberts, A. W., White, R. S., Lunnon, Z. C., Christie, P. A. F., Spitzer, R. \& iSIMM Team 2005. Imaging magmatic rocks on the Faroes Margin. In: Doré, A. G. \& Vining, B. A. (eds) Petroleum Geology: North-West Europe and Global Perspectives - Proceedings of the 6th Petroleum Geology Conference. Geological Society, London, 755-766.

Roberts, D. G. 1975. Marine geology of Rockall Plateau and Trough. Philosophical Transactions of the Royal Society, London, A278, 447-509.

Roberts, D. G., Bishop, D. G., Laughton, A. S., Ziolkowski, A. M., Scrutton, R. A. \& Matthews, D. H. 1970. New sedimentary basin on Rockall Plateau. Nature, 225, 170-172. 
Roberts, D. G., Ardus, D. A. \& Dearnley, D. A. 1973. Pre-Cambrian rocks drilled from the Rockall Bank. Nature, 244, 21-23.

Scrutton, R. A. 1972. The crustal structure of Rockall Plateau Microcontinent. Geophysical Journal of the Royal Astronomical Society, 27, 259-275.

Smallwood, J. R. \& White, R. S. 2002. Ridge-plume interaction in the North Atlantic and its influence on continental break-up and seafloor spreading. In: Jolley, D. W. \& Bell, B. R. (eds) The North Atlantic Igneous Province: Stratigraphy, Tectonic, Volcanic and Magmatic Processes. Geological Society, London, Special Publications, 197, $15-37$.

Smallwood, J. R., Staples, R. K., Richardson, K. R., White, R. S. \& FIRE Working Group 1999. Crust generated above the Iceland mantle plume: from continental rift to oceanic spreading centre. Journal of Geophysical Research, 104, 22885-22902.

Smythe, D. K. 1989. Rockall Trough - Cretaceous or Late Palaeozoic? Scottish Journal of Geology, 25, 5-43.

Spence, D., White, R. S., Westbrook, G. K. \& Fowler, S. R. 1989. The Hatton Bank continental margin-I. Shallow structure from two-ship expanding spread seismic profiles. Geophysical Journal, 96, $273-294$.

Srivastava, S. P. 1978. Evolution of the Labrador Sea and its bearing on the early evolution of the North Atlantic. Geophysical Journal of the Royal Astronomical Society, 52, 313-355.

Vogt, U., Makris, J., O’Reilly, B. M., Hauser, F., Readman, P. W., Jacob, A. W. B. \& Shannon, P. M. 1998. The Hatton Basin and continental margin: Crustal structure from wide-angle seismic and gravity data. Journal of Geophysical Research, 103(B6), 12545-12566.

White, N. J. \& Lovell, B. 1997. Measuring the pulse of a plume with the sedimentary record. Nature, 387, 888-891.

White, R. S. 1992. Crustal structure and magmatism of North Atlantic continental margins. Journal of the Geological Society, London, 149, $841-854$.

White, R. S. 1997. Rift-plume interaction in the North Atlantic. Philosophical Transactions of the Royal Society, London, Series A, 355, 319-339.

White, R. S. \& McKenzie, D. P. 1989. Magmatism at rift zones: The generation of volcanic continental margins and flood basalts. Journal of Geophysical Research, 94, 7685-7729.

White, R. S., Spence, G. D., Fowler, S. R., McKenzie, D. P., Westbrook, G. K. \& Bowen, A. N. 1987. Magmatism at rifted continental margins. Nature, 330, 439-444.

White, R. S., Christie, P. A. F., Kusznir, N. J., Roberts, A. M., Davies, A. Hurst, N. W., Lunnon, Z., Parkin, C. J., Roberts, A. W., Smith, L. K., Spitzer, R., Surendra, A. T. \& Tymms, V. 2002. iSIMM pushes frontiers of marine seismic acquisition. First Break, 20, 782-786.

Zelt, C. A. \& Smith, R. B. 1992. Seismic traveltime inversion for 2-D crustal velocity structure. Geophysical Journal International, 108, 16-24.

Ziolkowski, A., Hanssen, P., Gatliff, R., Li, X. \& Jakubowicz, H. 2001. The Use of Low Frequencies for Sub-Basalt Imaging. Expanded Abstracts, 71st Annual International Meeting, Society of Exploration Geophysicists, 74-77. 